\title{
Fresh Coconut Milk Versus Convenience Coconut Milk in Malay Cooking
}

\author{
Mohd Syafiq Othman ${ }^{1}$, Siti Nur Hanisah Zainol², Muhammad Ikmal Norshaidi \\ Norfezah Md Nor ${ }^{4}$ \\ \{ syafiqo@uitm.edu.my ${ }^{1}$, sitinorhanisah@gmail.com², ikmalplc686@gmail.com³ \\ norfezah420@uitm.edu.my ${ }^{4}$ \\ ${ }^{1,2,3,4}$ Faculty of Hotel and Tourism Management, Universiti Teknologi MARA, Cawangan Pulau, \\ Pinang, Jalan Permatang Pauh, 13500 Seberang Prai, Pulau Pinang, Malaysia
}

\begin{abstract}
This study was conducted to determine the most suitable coconut milk concentration in 'Masak Lemak Cili Api' gravy and to differentiate fresh coconut milk and convenience coconut milk used in the pertaining dish. Sensory evaluation was carried out using nine (9) likert point hedonic scale to determine the respondent's acceptability towards the dishes. The sensory result showed the convenience coconut milk has the same standard as a fresh coconut milk in this dish. The respondents were found could not differentiate between fresh coconut milk and convenience coconut milk used in Masak Lemak Cili Api.
\end{abstract}

Keywords: Fresh coconut milk, Convenience coconut milk, Concentration, Sensory Evaluation, Malay Cooking.

\section{Introduction}

Malaysia is a multiracial country with many different ethnic groups dominated by Malay, Chinese and Indian [1] which has their own unique, exciting and characteristics of foods [2]. Malay is the dominant ethnic group in this country. Malay food can be defined as a variety of local food that have a unique identity within the Malay people. All 14 states in Malaysia have their own iconic dish. For example, Kelantan is known for its 'ayam percik kuah putih' while Perak and Pahang known for its 'rendang tok' and 'opor daging'. These are the signature dish that usually served during the festive celebration or special occasion [2].

In Negeri Sembilan, coconut milk is widely used as their main ingredient in cooking. 'Masak Lemak Cili Api' is the iconic food of Negeri Sembilan [3]. The common ingredients used in that dish were buffalo meat while turmeric gives the yellow color of the gravy and the spiciness comes from the bird's eyed chilies and the richness of the dish comes from coconut milk. Researcher has mentioned in his study without coconut milk, there is no 'Masak Lemak Cili Api'

Coconut milk has been used in Malay cuisine not only as a thickener but also to harmonize flavor and texture. Most of the traditional foods in Malaysia such as curries and desserts contain coconut milk as their main ingredient [4]. It is an important raw material in home cooking as well as in the food processing industries.

Because of the uniqueness of the dish, this study focused on the consistency of coconut milk for 'Masak Lemak Cili Api'. There are many recipes but none of them focus on the concentration of the coconut milk and structure standard recipe that used as a standard in 
cooking 'Masak Lemak Cili Api'. Recently, there is an issue and misunderstanding about Malaysian food where 'Rendang' has been misconstrued by the judges of MasterChef UK that 'Rendang' need to be crispy.

As Malaysian, we need to preserve our heritage food and bring this dish with a structured standard recipe to be known to the world. Therefore, this study aims to determine the most suitable coconut milk concentration for 'Masak Lemak Cili Api' gravy and to differentiate fresh coconut milk and convenience coconut milk used in Masak Lemak Cili Api'.

\section{Literature Review}

\subsection{Masak Lemak Cili Api}

Negeri Sembilan is influenced by the migration of the Minangkabau from Sumatra [5]. The state has wide assemblage of culinary delights and the dishes are characteristically hot and spicy, often enhanced by 'cili padi' or bird's eye chilies. The iconic and popular dish in Negeri Sembilan is 'Masak Lemak Cili Api' with the combination of lemongrass, bird's eye chilies and fresh turmeric that are simmered in coconut milk to produce a wonderful aroma and mouthwatering dish. The use of coconut milk in Negeri Sembilan can be notice by its iconic dishes.

Masak Lemak Cili Api is known by its spiciness, fatty gravy and its eye catching colour, yellow. Spicy is the main factor for Masak Lemak Cili Api .In addition, the most popular meat item in Masak Lemak Cili Api is a buffalo meat, 'Ayam kampung', quail and catfish that have been smoked for hours with a selected firewood.

\subsection{Coconut Milk}

The sources of thickener for Malay cuisine is coconut milk and it is also for the harmonies blend of flavor and aroma to the dishes [4]. Coconut milk comes from the white flesh of mature brown coconut and it has thick consistency and rich creamy texture. Traditionally in Malaysia, the grated coconut flesh is squeezed by hand to produce the milk. Coconut milk can be classified as either thick coconut milk and thin coconut milk. The coconut milk is considered not good for health but it is currently not true. In fact, coconut milk contains many nutrients that needed for our body.

Coconut milk contains high nutritional value and rich in fiber, vitamin C, E, B1, B5 and B6 and also contains minerals such as iron, selenium, sodium, calcium, magnesium and phosphorus [6]. The health benefit of coconut milk is it can keep the heart healthy, aids weight loss, boost immune systems, improve digestion and relives constipation, strengthen the bones, control diabetes, prevent anemia, clam the nerve cells and prevent stomach ulcer.

\section{Research Methodology}

\subsection{Formulation}

In a blender, birds eye chilies, fresh turmeric, lemongrass and coarse salt is blended together to make a paste. In a pot, add the blended ingredients and cubed whole leg chicken. Cooked for a while until the jus of the chicken come out. After that, pour in the coconut milk and tamarind peel, constantly stir until the chicken cooked and make sure the temperature is controlled until simmering point. A $200 \mathrm{gm}$ grated coconut and $80 \mathrm{ml}$ water is added into 600 W Philips blender. The rotation of the blender is set for 15 seconds. The results of the same 
concentration for both coconut milk is equal because both of them have been adjusted into a same desired consistency.

\subsection{Spread Test}

The spread test that have been apply in this study consist of two method, which is scale and time. The scaled silicon mat is used and the time is taken by the stopwatch. Next, two different type of coconut milk is poured onto two scaled silicon mat and at the same moment, the time is taken by the stopwatch.

\subsection{Sensory Evaluation}

The main objective of sensory evaluation in this study to determine the most suitable coconut milk concentration in Masak Lemak Cili Api. The respondent was also asked to ranked the product from the least preferer to the most preferer.

Thirty (30) respondents of Degree and Diploma of Culinary arts students in UiTM Permatang Pauh, Pulau Pinang is randomly picked, to evaluate the research product without any knowledge of the ingredients of the product. The respondents were asked to evaluate the overall acceptability, color, smell, taste and texture by a nine-point hedonic scale [19].

\subsection{Data Analysis}

All the data collected will be key-in in the SPSS version 21.0 by using One Way ANOVA and Microsoft Excel by using a spiderweb.

\section{Results and Discussions}

\subsection{Spread Test}

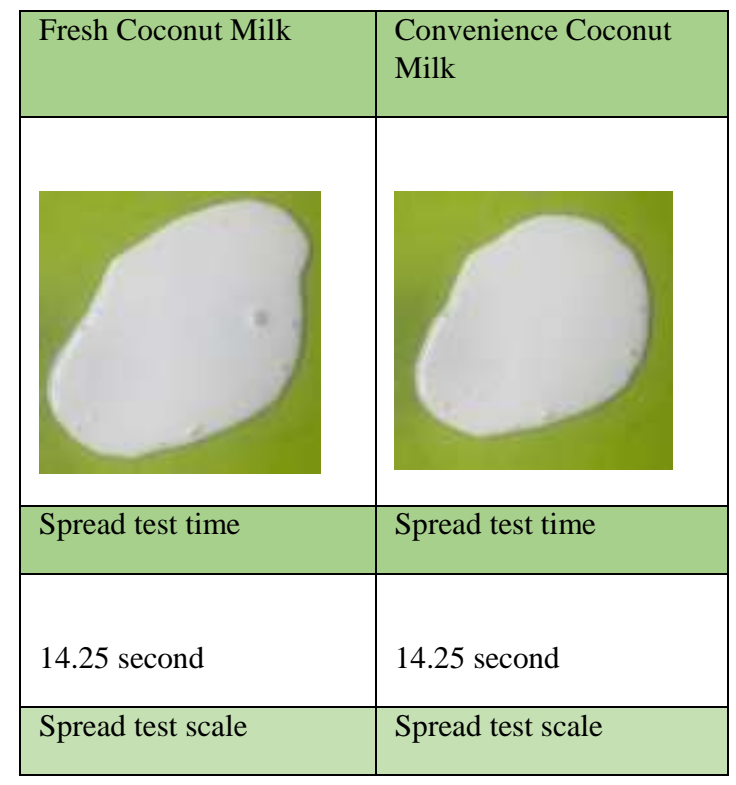

Fig. 1. The spread test result between fresh coconut milk and convenience coconut milk. 


\subsection{Descriptive Analysis}

\subsubsection{Color}

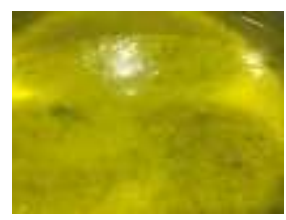

Fig 2. .Effect of 'Masak Lemak Cili Api' using fresh coconut milk

Fresh coconut milk contains no preservatives, thefore the consistency of the dish is lighter and soupier and the color is a little bit darker.

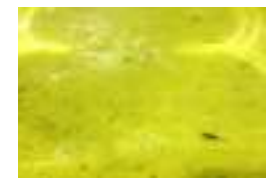

Fig 3 . Effect of 'Masak Lemak Cili Api' using convenience coconut milk.

The texture of the gravy was found a little bit thicker and the color is brighter when convenience coconut milk is used in the 'Masak Lemak Cili Api'.

The usage of Fresh coconut milk was not significant $(\mathrm{P}>0.05,0.191)$ change the color of 'Masak Lemak Cili Api'. However, the convenience coconut milk was also found not significantly affect the color of 'Masak Lemak Cili Api'.

\subsubsection{Consistency}

The usage of fresh coconut milk not significant $(\mathrm{P}>0.05,0.137)$ changed the consistency of 'Masak Lemak Cili Api'. However, the Convenience coconut milk was also found not significantly affect the consistency of 'Masak Lemak Cili Api'.

\subsubsection{Taste}

The usage of Fresh coconut milk not significant $(\mathrm{P}>0.05,0.157)$ changed the taste of 'Masak Lemak Cili Api'. However, the Convenience coconut milk was found not significantly affect the taste of 'Masak Lemak Cili Api'.

\section{Conclusion}

As a conclusion, the respondents could not detect the coconut milk. whether it is fresh coconut milk and convenience coconut milk. People nowadays get used to accepting the 
convenience coconut milk in their daily life. Due to the issue, it can be related with the undetectable taste between fresh coconut milk and convenience coconut milk. The overall result is that the respondent prefers both two different type of coconut milk in 'Masak Lemak Cili Api'.

Acknowledgments. The authors would like to thank to Universiti Teknologi MARA, Cawangan Pulau Pinang, Malaysia.

\section{References}

[1] K. Yoshino, M. Kubo, M. Z. Suhaimi, M. Salehuddin, and M. Zahari, "Common Acceptable Cuisine in Multicultural Countries: Towards Building the National Food Identity," Glob. \nFood Soc. Identities Asia Pacific Reg., 2014.

[2] M. N. A. Raji, S. Ab Karim, F. A. C. Ishak, and M. M. Arshad, "Past and present practices of the Malay food heritage and culture in Malaysia," Journal of Ethnic Foods. 2017.

[3] A. Zainal and S. Alam, "MALAYSIAN GASTRONOMY ROUTES AS A TOURIST," J. Tour. Hosp. Culin. Arts, 2010.

[4] A. M. Marina and S. NurulAzizah, "Use of Coconut Versus Dairy Milk Products in Malaysian Dishes: Comparison of Nutritional Composition and Sensory Evaluation," J. Food Nutr. Res., 2014.

[5] I. Mohd Salehuddin, M.Z., Hanitta, M.S., Mohd Shazali, M.S., Norazmir, M.N. \& Noriza, "Malay Traditional Food Knowledge and Young Generation Practices," Sci. Ser. Data Rep., 2013.

[6] F. Agyemang-Yeboah, "Health Benefits of Coconut (Cocos nucifera Linn.) Seeds and Coconut Consumption," in Nuts and Seeds in Health and Disease Prevention, 2011. 